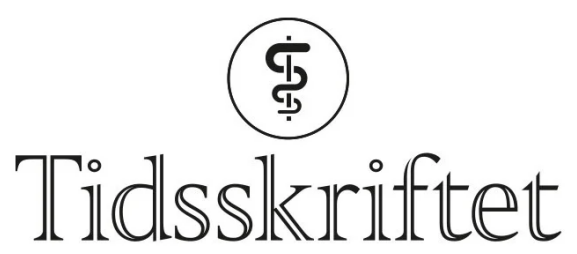

DEN NORSKE LEGEFORENING

\title{
J.M. Haga svarer
}

\author{
KOMMENTAR
}

JON MAGNUS HAGA

jon.magnus.haga@gmail.com

Jon Magnus Haga er leder av Norsk senter for maritim medisin og dykkemedisin, Helse Bergen og førsteamanuensis ved Institutt for global helse og samfunnsmedisin, Universitetet i Bergen. Forfatteren har ikke oppgitt noen interessekonflikter.

Jeg takker Torkel Steen for hans kommentar til min kronikk om den humanitære situasjonen i Middelhavet (1). Jeg er enig med Steen i at migrasjon reiser komplekse problemstillinger og utfordrer oss i et skjæringspunkt mellom medisin, etikk og politikk. Mitt mål med kronikken var å gi et innblikk i de menneskelige lidelsene i havområdene utenfor Libya, med utgangspunkt i mine erfaringer som skipslege.

Det stemmer som Steen antyder at det tidligere har blitt lansert teorier om at sjøredning fungerer som en trekkfaktor på flyktninger til Middelhavet og bidrar til at flere mennesker legger ut på mer farefulle reiser. Slike teorier finner imidlertid ikke støtte i litteraturen. Tvert imot, undersøkelser av migrasjon i Det libyske hav har vist at det ikke er en slik sammenheng mellom tilgjengelighet av redningsressurser og antall mennesker som satte til havs fra Libya i perioden fra $2014(2,3)$. Analysene gir derimot klare holdepunkter for at det var sammenhenger mellom tiltak iverksatt av europeiske myndigheter for å hindre migrasjon fra Libya og økning i migrasjon langs mer risikable migrasjonsruter.

Steen understreker at båtflyktninger ikke passer inn i en tradisjonell definisjon av sjøfolk. Det er jeg enig i. Jeg opplever imidlertid poenget å være underordnet i en diskusjon om sjøredning. Havretten gjelder for alle som ferdes til sjøs. Plikten til å hjelpe gjelder uavhengig om den skipbrudne er sjømann, fisker, fergepassasjer, cruiseturist, fritidsseiler eller - som var tema for kronikken - flyktning i Middelhavet. Konsekvensene av å være hjelpeløst forlatt i åpent hav er den samme, uavhengig av formålet med en sjøreise eller hvordan vi definerer sjøfolk.

Ingen legger ut på livsfarlige reiser over havet om de kan la være. Ingen forlater hjemmene sine, alt de eier og alle de kjenner om livet er godt der de er. Flukt handler om umulige valg og om store ofre. Flukt handler også om mot. Pave Francis hyllet nylig som helter dem på flukt for å beskytte sine barn og sin familie (4). Perspektivet er tankevekkende. Kanskje ville det være nyttig å ta med seg mer av dette perspektivet inn i innvandringsdebatten også her hjemme?

Hvordan vi møter mennesker i nød sier noe om hvem vi er. Og hvem vi ønsker å være. Sjøredning handler om mennesker. Ingen kan gjøre alt, men jeg er sikker på at Norge kan gjøre mer. 


\section{REFERENCES}

1. Haga JM. Norge - sjøfartsnasjonen som lar mennesker drukne. Tidsskr Nor Legeforen 2021; 141. doi: 10.4045/tidsskr.21.0568. [PubMed][CrossRef]

2. Cusumano E, Villa M. Sea rescue NGOs: a pull factor of irregular migration? Policy Briefs 2019/22, Migration Policy Centre 2019. DOI: 10.2870/644458

3. Heller C, Lorenzo P. Blaming the Rescuers. Criminalizing Soldiarity, recinforcing Deterrence. Forensic Architecture Agency, Goldsmith University 2018. (https://blamingtherescuers.org/report/) Lest 3.2.2022.

4. Monda A, Gisotti A. Parents who face challenges for the sake of their children are heroes. L'Osservatore Romano 2022. https://www.osservatoreromano.va/en/news/2022-01/ing-002/parentswho-face-challenges-for-the-sake-of-their-children-are-h.html Lest 3.2.2022.

Publisert: 28. februar 2022. Tidsskr Nor Legeforen. DOI: 10.4045/tidsskr.22.0108

(C) Tidsskrift for Den norske legeforening 2023. Lastet ned fra tidsskriftet.no 26. april 2023. 